\title{
Amorphophallus adamsensis (Araceae), a new species from llocos Norte, Philippines
}

\author{
L.M. Magtoto1, D.G. Mones ${ }^{1}$, K.A. Ballada1 , C.M. Austria1, R.M. Dizon¹, \\ W.V. Alangui ${ }^{2}$, A.A. Reginaldo ${ }^{1}$, W.M. Galvan ${ }^{1}$, K.T. Dizon ${ }^{1}$, W.L.A. Hetterscheid ${ }^{3}$
}

Key words

Amorphophallus

Araceae

Ilocos Norte

new species

Philippines
Abstract There are ten known species of Amorphophallus in the Philippines, and an eleventh is herein described
and named as Amorphophallus adamsensis. It resembles A. dactylifer and A. rostratus. Diagnostic characters of this new species are provided.

Published on 12 December 2013

\section{INTRODUCTION}

There are 213 known species of Amorphophallus Blume ex Decne. (Hetterscheid 1996-2013) distributed in Asia, Africa, Madagascar, Malay Archipelago, Australia and Melanesia (Mayo et al. 1997). Ten species are known in the Philippines, viz. A. dactylifer Hett., A. declinatus Hett., A. longispathaceus Engl. \& Gehrm., A. luzoniensis Merr., A. merrillii Hett., A. paeonifolius (Dennst.) Nicolson, $A$. palawanensis Bogner \& Hett., A. rostratus Hett., $A$. salmoneus Hett., and $A$. natolii Hett., Wistuba, V.B.Amoroso, Medecilo \& Claudel (Pelser et al. 2011 onwards, Hetterscheid et al. 2012). Of these, only A. paeonifolius is non-endemic (Hetterscheid 1994, 1996-2013, Hetterscheid et al. 2012).

A new species is hereby presented as Amorphophallus adamsensis L.M.Magtoto, D.G.Mones, K.A.Ballada, C.M.Austria, R.M.Dizon, W.V.Alangui, A.A.Reginaldo, W.M.Galvan, K.T.Dizon \& Hett. This was seen from the locality of Adams, llocos Norte, Philippines. Photos of the plant were initially identified by colleagues as $A$. dactylifer, but it was found to be different after a closer examination of its inflorescence. The species description is based on single specimen of leaf, inflorescence, and infructescence.

Amorphophallus adamsensis L.M.Magtoto, D.G.Mones, K.A.Ballada, C.M.Austria, R.M.Dizon, W.V.Alangui,

A.A.Reginaldo, W.M.Galvan, K.T.Dizon \& Hett., sp. nov. Plate 1, 2

Type: LKD 130 (holo University of the Philippines Baguio Northern Luzon Herbarium), Philippines, Adams, llocos Norte, elevation $303 \pm 3$ m, 27 May 2013.

Etymology. The species epithet refers to the locality where this species was found.

Tuber depressed globose, $17 \mathrm{~cm}$ diam and $10 \mathrm{~cm}$ high, fusiform offsets numerous on upper half close to peduncle/petiole base.

\footnotetext{
Department of Biology, College of Science, University of the Philippines Baguio, Baguio City, 2600 The Philippines; corresponding author e-mail: Izel_m@yahoo.com.

2 Department of Mathematics and Computer Science, College of Science, University of the Philippines Baguio, Baguio City, 2600 The Philippines.

${ }^{3}$ Von Gimborn Arboretum, Velperengh 13, 3941 BZ Doorn, The Netherlands.
}

Leaf solitary; petiole $123 \mathrm{~cm}$ long, $3 \mathrm{~cm}$ diam, background colour dark greyish to purple green, with numerous elliptical light greyish to purple markings with slightly raised to raised margins at lower half and diamond-shaped markings on upper part; lamina $139 \mathrm{~cm}$ diam, rachises winged distal from the basal branching, basal parts naked with few petiolulate leaflets; leaflets oval to elongate elliptic, $9.5-24 \mathrm{~cm}$ long, $3.5-6 \mathrm{~cm}$ in width, long acuminate (acumen $2.5-5 \mathrm{~cm}$ long), glossy green above. Inflorescence solitary, long peduncled; peduncle $158 \mathrm{~cm}$ long, $3.5 \mathrm{~cm}$ diam, green to purplish brown background, having generally elliptic whitish green to whitish purple markings with lighter raised margins; spathe narrow triangular, $53 \mathrm{~cm}$ long, $28 \mathrm{~cm}$ diam; base strongly convolute, subglobose, with distinct constriction from the lateral-ventral sides distinguishing it from the limb; base outside light green with purplish hue, with scattered irregularly shaped slightly raised whitish green spots; base inside light green with white spots, lower part clothed with purple to brown unbranched finger-like projections; limb 3 times longer than base, adpressed against the appendix, strongly costate at the centre, pale green costa and veins; limb inside purple to brown with white spots, limb outside the same; limb auriculate; spadix sessile, much longer than spathe, $99 \mathrm{~cm}$ long; female zone cylindric, $9 \mathrm{~cm}$ long, c. $3.5 \mathrm{~cm}$ diam, flowers slightly distant; male zone cylindric, $12 \mathrm{~cm}$ long, $3 \mathrm{~cm}$ diam at the top, flowers distant; appendix narrowly fusiform to narrowly elongate, top subacute, $79 \mathrm{~cm}$ long, base with few short shallow ridges, dark reddish purple; ovaries depressed globose, $4 \mathrm{~mm}$ diam, $3 \mathrm{~mm}$ high, unilocular, basal placentation; style $3 \mathrm{~mm}$ long, $1 \mathrm{~mm}$ diam, slightly curvate, dark purple; stigma large, deeply 3-lobed, surface white, with numerous thin finger-like projections; fruit with globular base and conical tip, $4 \mathrm{~mm}$ high, $3.5 \mathrm{~mm}$ diam; pollen bright orange.

Notes - Amorphophallus adamsensis resembles A. dactylifer and $A$. rostratus (Table 1 ) but can be distinguished from both by having much longer leaflets with longer acumen; narrow triangular and much longer spathe, the base of which is clothed inside with purple to brown unbranched finger-like projections; lobed or auriculate limb; and much longer male zone with distant flowers.

In addition, $A$. adamsensis differs from $A$. dactylifer by having a longer peduncle, narrower spathe, and a much longer spadix 
Table 1 Comparison of the morphology of $A$. adamsensis with A. dactylifer and A. rostratus.

\begin{tabular}{|c|c|c|c|}
\hline Characters & A. adamsensis & A. dactylifer & A. rostratus \\
\hline Tuber diam & $17 \mathrm{~cm}$ & $7-16 \mathrm{~cm}$ & c. $10 \mathrm{~cm}$ \\
\hline Tuber height & $10 \mathrm{~cm}$ & $3-9 \mathrm{~cm}$ & c. $8 \mathrm{~cm}$ \\
\hline Petiole length & $123 \mathrm{~cm}$ & to c. $140 \mathrm{~cm}$ & $30-100 \mathrm{~cm}$ \\
\hline Petiole diam & $3.5 \mathrm{~cm}$ & to $\mathrm{c} .6 \mathrm{~cm}$ & $1-2 \mathrm{~cm}$ \\
\hline Petiole colour & dark greyish to purple green & $\begin{array}{l}\text { background colour greyish green } \\
\text { (reddish when young) }\end{array}$ & pale green or olive green \\
\hline Petiole markings & $\begin{array}{l}\text { elliptic, light greyish to purple markings } \\
\text { with slightly raised to raised margins at } \\
\text { lower half }\end{array}$ & $\begin{array}{l}\text { elliptic to elongate-elliptic, whitish or green } \\
\text { spots, the latter with a whitish margin, those } \\
\text { at the base of the petiole strongly raised, } \\
\text { crust-like, upper part of petiole with obscure, } \\
\text { dark reddish brown, narrowly elliptic to near- } \\
\text { linear spots }\end{array}$ & $\begin{array}{l}\text { larger and smaller, orbicular, whitish } \\
\text { greenish spots and tiny, blackish green } \\
\text { dots, not raised }\end{array}$ \\
\hline Lamina diam & $139 \mathrm{~cm}$ & to c. $180 \mathrm{~cm}$ & $50-100 \mathrm{~cm}$ \\
\hline Rachis & $\begin{array}{l}\text { winged distal from the basal branching; } \\
\text { basal part naked with a few petiolulate } \\
\text { leaflets }\end{array}$ & $\begin{array}{l}\text { winged distal from the basal branchings, } \\
\text { basal part naked with a few petiolulate } \\
\text { leaflets }\end{array}$ & rachises narrowly winged all over \\
\hline Leaflet shape & oval to elongate elliptic & elliptic or elliptic-lanceolate & lanceolate \\
\hline Leaflet length & $9.5-24 \mathrm{~cm}$ & to $\mathrm{c} .18 \mathrm{~cm}$ & $3-7 \mathrm{~cm}$ \\
\hline Leaflet width & $3.5-6 \mathrm{~cm}$ & to c. $6 \mathrm{~cm}$ & $0.5-2 \mathrm{~cm}$ \\
\hline Acumen length & $2.5-5 \mathrm{~cm}$ & up to $3 \mathrm{~cm}$ & $3-4 \mathrm{~cm}$ \\
\hline Peduncle length & $158 \mathrm{~cm}$ & $60-130 \mathrm{~cm}$ & $150 \mathrm{~cm}$ \\
\hline Peduncle diam & $3.5 \mathrm{~cm}$ & $1-3.5 \mathrm{~cm}$ & $2.5 \mathrm{~cm}$ \\
\hline Peduncle colour & green to purplish brown & as petiole & pale olive green with very faint spots \\
\hline Spathe shape & $\begin{array}{l}\text { narrow triangular (limb is three times } \\
\text { longer than wide) }\end{array}$ & elongate triangular, acute & elongate triangular \\
\hline Spathe base outside & $\begin{array}{l}\text { light green with purplish hue and with } \\
\text { scattered irregularly shaped whitish } \\
\text { green spots }\end{array}$ & $\begin{array}{l}\text { pale dirty greenish with scattered white, } \\
\text { slightly raised spots }\end{array}$ & uniformly pale green \\
\hline Spathe base inside & $\begin{array}{l}\text { light green with white spots; clothed with } \\
\text { purple to brown, unbranched finger-like } \\
\text { projections }\end{array}$ & $\begin{array}{l}\text { dark purple with pale upper part; densely } \\
\text { clothed with short and long, conic warts, } \\
\text { these sometimes branched or flaky, purple }\end{array}$ & $\begin{array}{l}\text { inside uniformly green, with numerous, } \\
\text { large, irregular warts, aligned into vertical } \\
\text { ridges }\end{array}$ \\
\hline Spathe limb position & arching over & arching over & erect, helically twisted \\
\hline Spathe limb outside & $\begin{array}{l}\text { colour and marking same as inside; lobed } \\
\text { or auriculate; strongly costate with light } \\
\text { green veins outside }\end{array}$ & $\begin{array}{l}\text { brown with white spots, strongly costate } \\
\text { along the centre, margins sometimes } \\
\text { slightly involute }\end{array}$ & pale dull purple \\
\hline Spathe limb inside & purple to brown with white spots & $\begin{array}{l}\text { dull dark reddish purple with scattered, } \\
\text { distinct or faint, pale purple dots to whitish } \\
\text { purple spots }\end{array}$ & slightly darker than outside \\
\hline Spathe length & $53 \mathrm{~cm}$ & $30-42 \mathrm{~cm}$ & $20-45 \mathrm{~cm}$ \\
\hline Spathe diam & $28 \mathrm{~cm}$ & $32-36 \mathrm{~cm}$ & $12-30 \mathrm{~cm}$ \\
\hline Spadix length & c. $99 \mathrm{~cm}$ & $42-60 \mathrm{~cm}$ & $35-90 \mathrm{~cm}$ \\
\hline Female zone shape & cylindric & cylindric & cylindric or slightly conic \\
\hline Female zone length & $9 \mathrm{~cm}$ & $4-8.5 \mathrm{~cm}$ & $4-5 \mathrm{~cm}$ \\
\hline Female zone diam & $3.5 \mathrm{~cm}$ & $2.5-4 \mathrm{~cm}$ & c. $1.5 \mathrm{~cm}$ \\
\hline Male zone & cylindric & elongate obconic or cylindric & cylindric \\
\hline Male zone length & $12 \mathrm{~cm}$ & $4.5-6.5 \mathrm{~cm}$ & $4-5 \mathrm{~cm}$ \\
\hline Male zone diam & $3 \mathrm{~cm}$ & $1.5-3 \mathrm{~cm}$ & $1.5-3 \mathrm{~cm}$ \\
\hline Male flowers & distant & congested & congested \\
\hline Appendix shape & $\begin{array}{l}\text { narrowly fusiform to narrowly elongate, } \\
\text { top subacute }\end{array}$ & elongate conic, top obtuse or subacute & narrowly elongate conic, top subacute \\
\hline Appendix length & $79 \mathrm{~cm}$ & $31-46 \mathrm{~cm}$ & $27-75 \mathrm{~cm}$ \\
\hline Appendix base and colour & $\begin{array}{l}\text { with few shallow, short ridges; dark } \\
\text { reddish purple }\end{array}$ & ridged; dark purple & $\begin{array}{l}\text { with some scattered, shallowly conic } \\
\text { staminodes; dark purple }\end{array}$ \\
\hline Ovary shape & depressed globose & subglobose or depressed globose & ovoid, circular in cross section \\
\hline Ovary diam & $4 \mathrm{~mm}$ & $2-3 \mathrm{~mm}$ & $2 \mathrm{~mm}$ \\
\hline Ovary height & $3 \mathrm{~mm}$ & $2-2.5 \mathrm{~mm}$ & $2.5 \mathrm{~mm}$ \\
\hline Style length & $3 \mathrm{~mm}$ & $2-5 \mathrm{~mm}$ & $0.8 \mathrm{~mm}$ \\
\hline Style diam & $1 \mathrm{~mm}$ & $0.8-1 \mathrm{~mm}$ & c. $0.5 \mathrm{~mm}$ \\
\hline Stigma & deeply 3-lobed & shallowly or deeply 2- or 3-lobed & $\begin{array}{l}\text { mostly } 3 \text {; one lobe very long, conical, the } \\
\text { others shorter }\end{array}$ \\
\hline Fruit & globular base with conical tip & ovoid & unknown \\
\hline Fruit size & $4 \mathrm{~mm}$ high; $3.5 \mathrm{~mm}$ diam & unknown & unknown \\
\hline
\end{tabular}


and appendix; from $A$. rostratus by having a longer and larger petiole with elliptic markings, a larger lamina with naked basal rachis, much longer and larger oval to elongate elliptic leaflets, arching over limb, a longer and larger female zone, depressed globose ovaries, and longer and larger styles.

Acknowledgement The authors are grateful to the Foundation for the Philippine Environment (FPE) for research funding and for the invaluable help of Dr. Alan Galloway, For. John Rey Callado of the Philippine National Museum, the Botanical Library of the National Herbarium of the Netherlands and their staff, and Claire Hill of IngentaConnect.

\section{REFERENCES}

Hetterscheid W. 1994. Notes on the genus Amorphophallus (Araceae) - 2 . New species from tropical Asia. Blumea 39: 237-281.

Hetterscheid W. 1996-2013. The Amorphophallus species. Retrieved 24 July 2013 from International Aroid Society website, www.aroid.org/genera/ generapage.php?genus=amorphophallus

Hetterscheid WLA, Wistuba A, Amoroso VB, Medecilo MP, Claudel C. 2012. Amorphophallus natolii (Araceae), a new species from limestone on Palawan, Philippines. Botanical Studies 53: 415-420.

Mayo SJ, Bogner J, Boyce PC. 1997. Amorphophallus. In: The genera of Araceae: 235-239. Royal Botanic Gardens, Kew.

Pelser PB, Barcelona JF, Nickrent DL. 2011. Co's Digital Flora of the Philippines. Retrieved 10 May 2013 from http://www.philippineplants.org/ CoFamsPDF/ARACEAE.pdf.

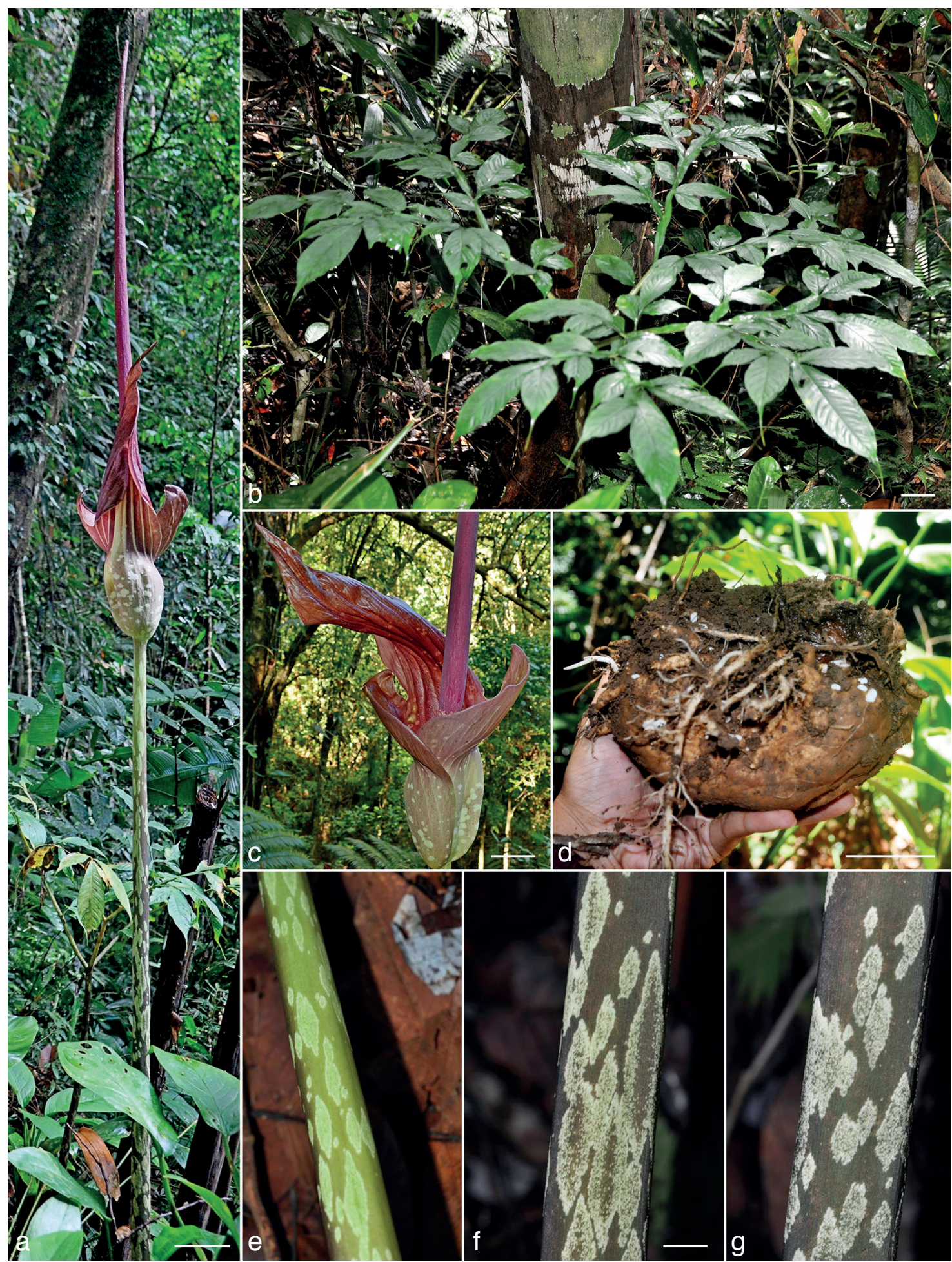

Plate 1 Amorphophallus adamsensis L.M.Magtoto, D.G.Mones, K.A.Ballada, C.M.Austria, R.M.Dizon, W.V.Alangui, A.A.Reginaldo, W.M.Galvan, K.T.Dizon \& Hett. a. Habit of inflorescence; b. habit of leaf; c. habit of spathe; d. tuber; e-g. peduncle. - Scale bars: $a=10 \mathrm{~cm} ; b-d=5 \mathrm{~cm} ; e-g=1 \mathrm{~cm}$. - Photos: a, b, d-g: L.M. Magtoto; c: D.G. Mones. 

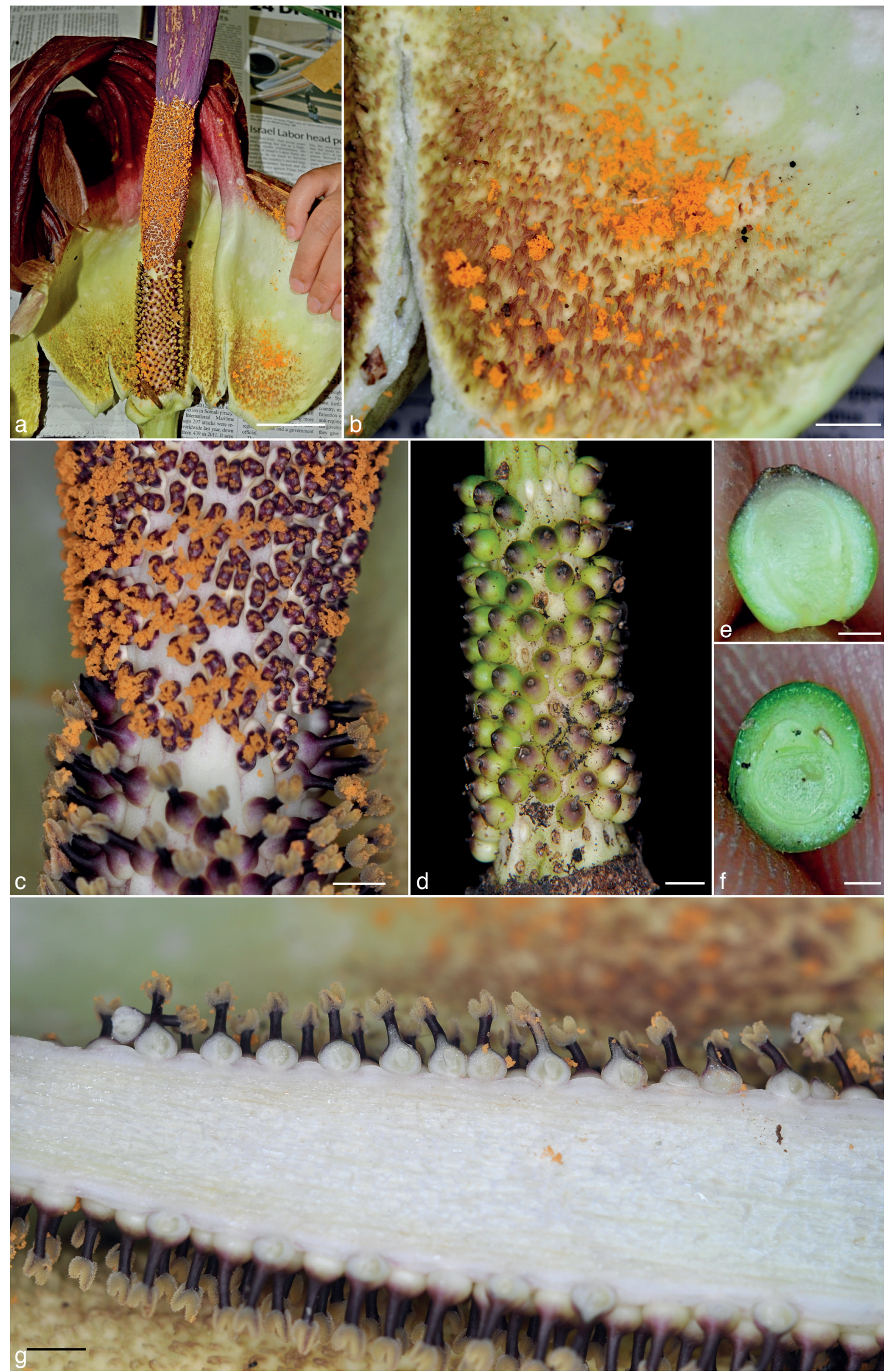

Plate 2 Amorphophallus adamsensis L.M.Magtoto, D.G.Mones, K.A.Ballada, C.M.Austria, R.M.Dizon, W.V.Alangui, A.A.Reginaldo, W.M.Galvan, K.T.Dizon \& Hett. a. Open spathe; b. spathe base; c. male and female flowers; d. infructescence; e. fruit (I.s.); f. fruit (c.s.); g. female zone (I.s.). $-\mathrm{Scale}$ bars: a $=5 \mathrm{~cm}$; $\mathrm{b}=1 \mathrm{~cm} ; \mathrm{c}, \mathrm{d}, \mathrm{g}=5 \mathrm{~mm} ; \mathrm{e}, \mathrm{f}=1 \mathrm{~mm}$. — Photos: a: D.G. Mones; b-g: L.M. Magtoto. 